\title{
Auto-immune thrombocytopenia after Measles Mumps Rubella MMR vaccination: molecular mimicry of measles virus phosphoprotein with platelet gpllb
}

\author{
Guy Mong Ky Tran ${ }^{1,2}$, Laurent Gerbaud ${ }^{1}$, Adrien Caprani ${ }^{2 *}$ \\ From $16^{\text {th }}$ International Symposium on HIV and Emerging Infectious Diseases \\ Marseille, France. 24-26 March 2010
}

\section{Background}

MMR vaccination is complicated by rare cases of autoimmune purpura or thrombocytopenia in a chronological delay of about 10-24 days, which corresponds to the rise of antibodies (Autret E, 1996; Vlacha V, 1996). We have demonstrated that in the cases of HIV-1, Parvovirus B19, Chikungunya virus, Leptospirosis, the culprit is an epitope localized on the platelet gpIIIaIIb, centred by a phenylalanine-proline (Tran MKG, ISHEID Toulon 2002); these auto-antibodies are very powerful and induce in mice a thrombocytopenia; allo-immunisation from mother to the newborn has the same epitope on gpIIIaIIb (Brouk H, 2009). We continue the same direction of research for MMR vaccine.

\section{Methods}

Comparison of amino acid sequences between gpIIIaIIb and viruses (measles, mumps and rubella).

\section{Results}

There is a molecular mimicry between gpIIb (P08514) and measles virus (strain MVi/Victoria.Aus/12.99) Phosphoprotein P (ABV24494) (Bankamp B, 2008), Table 1.

\section{Tabele 1}

\begin{tabular}{ll}
\hline platelet gpllb 782 & RGNSFP \\
\hline Measles virus P protein & 199-RGNSFP-204 \\
\hline
\end{tabular}

\section{Discussion}

The occurrence of thrombocytopenia 2 or 3 weeks after MMR vaccination is an auto-immune phenomenon, on a peculiar genetic background prone to make auto-antibodies against phenylalanine-proline containing epitopes. MMR vaccine must be avoided in these patients with idiopathic thrombocytopenia (Drachtman RA, 1994). The chronological argument is by itself convincing and confirmed here by the biological finding of the causal epitope on platelet. Thus we must be very cautious in presence of a MMR vaccine clinical auto-immune complication (such as autism) (Wakefield AJ) and not discard it as a simple coincidence, but rather try to elucidate its mechanism and genetics (HLA-DR4). The gpIIIaIIb epitope may serve as a chelating hapten for treatment.

\section{Author details}

'University of Auvergne, Hotel-Dieu Hospital, Clermont-Ferrand, France.

${ }^{2}$ Association Positifs, Paris, France.

Published: 11 May 2010

doi:10.1186/1742-4690-7-S1-P173

Cite this article as: Tran et al:: Auto-immune thrombocytopenia after Measles Mumps Rubella MMR vaccination: molecular mimicry of measles virus phosphoprotein with platelet gpllb. Retrovirology 2010 7(Suppl 1):P173.

* Correspondence: positifpresident@yahoo.fr

${ }^{2}$ Association Positifs, Paris, France 